AEC RESEARCH

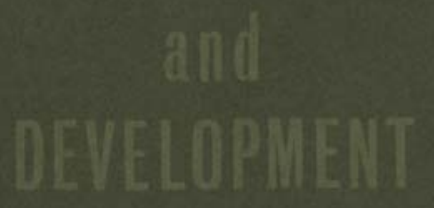

REPORT

\section{ELEVATED TEMPERATURE EXTENSOMETER FOR THE REMOTE TENSILE TESTING OF IRRADIATED SPECIMENS}

R. W. BARKER and P. K. McDANIEL

OCTOBER, 1965
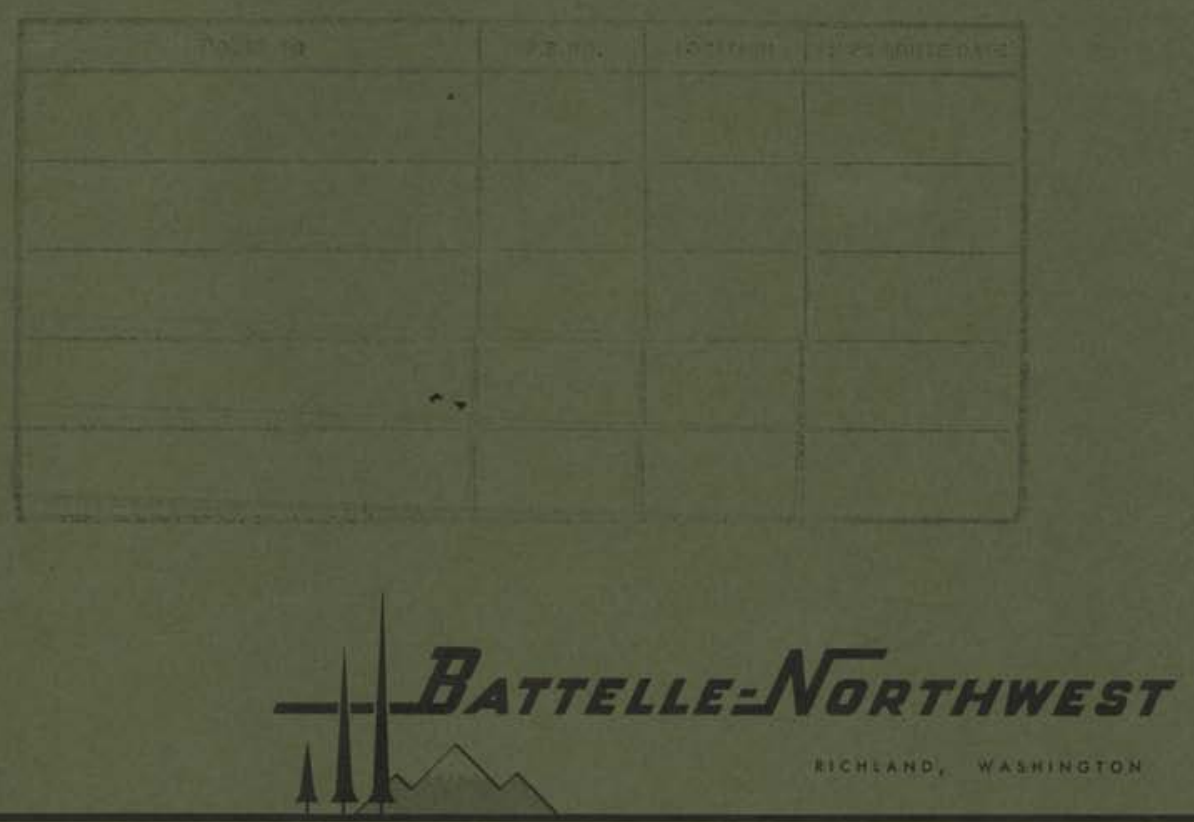

PACIFIC NORTHWEST LABORATORY operated by BATTELLE MEMORIAL INSTITUTE 


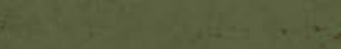

\section{LEGAL NOTICE}

This report was prepared as an account of Government sponsored work. Neither the United States, nor the Commission, nor any person acting on behalf of the Commission:

A. Makes any warranty or representation, expressed or implied, with respect to the accuracy, completeness, or usefulness of the information contained in this report, or that the use of any information, apparatus, method, or process disclosed in this report may not infringe privately owned rights; or

B. Assumes any liabilities with respect to the use of, or for damages resulting from the use of any information, apparatus, method, or process disclosed in this report.

As used in the above, "person acting on behalf of the Commission" includes any employee or contractor of the Commission, or employee of such contractor, to the extent that such employee or contractor of the Commission, or employee of such contractor prepares, disseminates, or provides access to, any information pursuant to his employment or contract with the Commission, or his employment with such contractor.

\section{PAOSIFIC NCDTHM/AEST LABORATORY}

RICHLAND, WASHINGTON

* operated by

BATTELLE MEMORIAL INSTITUTE

for tho

IINITFD STATES ATOMIC ENERGY COMMISSION. UNDER CONTRACT AT(45-1)-1830 


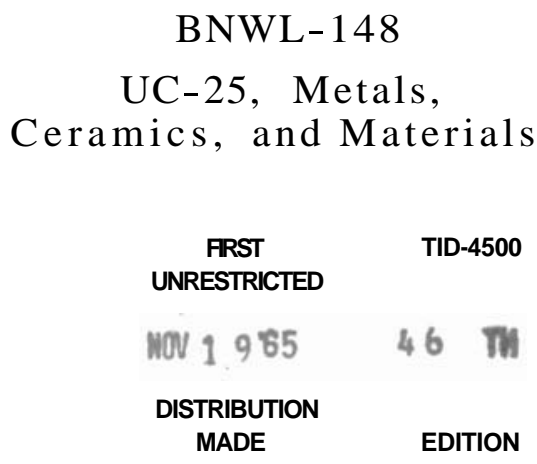

ELEVATED TEMPERATURE EXTENSOMETER

FOR THE REMOTE TENSILE TESTING

OF IRRADIATED SPECIMENS

\author{
By \\ R. W.. Barker and P. K. McDaniel \\ Reactor Metals Research Section \\ Reactor and Materials Technology Department
}

October, 1965

PACIFIC NORTHWEST LABORATORY

RICHLAND, WASHINGTON 



\section{ELEVATED TEMPERATURE EXTENSOMETER \\ FOR THE REMOTE TENSILE TESTING \\ OF IRRADIATED SPEICMENS}

\section{INTRODUCTION}

This paper describes adaptations made to a commercial tension extensometer to provide a means of accurately measuring strain to $500{ }^{\circ} \mathrm{C}$ by remote manipulation in radiometallurgy shielding facilities. Other components used in conjunction with the extensometer are also described.

Accurate strain measurements are required for most mechanical properties studies of metallic materials. A number of commercial extensometers are available for measuring strain under routine testing conditions. However, when strain measurements at elevated temperatures or in radiation-shielded facilities are required, many standard commercial systems are either ineffective or inaccurate. Consequently, it has been difficult to resolve some important effects of reactor environments and test temperature on tensile ductility parameters.

\section{SUMMA RY}

A standard commercial extensometer has been modified to provide direct strain measurements in various elevated-temperature environments with the accuracy of ASTM class B-1 standards and the simplicity of the parent model. This modified extensometer has been successfully employed with a remotized Instron machine in conducting several hundred tests of irradiated metals, alloys, and composite structures at temperatures to $500{ }^{\circ} \mathrm{C}$.

\section{DISCUSSION}

The objective of this work was todevelop a remotely operable extensometer for use at elevated temperatures with Instron* tensile machines.

* Instron Engineering Corporation, Canton, Mass. 
These machines are used extensively at Pacific Northwest Laboratory for testing both irradiated specimens in radiometallurgy cells and unirradiated control specimens.

Although the Instron can provide autographic stress-strain data by a number of means, the signal from. a Weidemann* extensometer is most widely used to drive the $\mathrm{Y}$-axis of an $\mathrm{X}-\mathrm{Y}$ recorder. The extensometer uses a linear variable differential transformer (LVDT) as a sensing unit and is coupled to a null balance circuit in the Instron control unit. An advantage of this extensometer is its ability to maintain a high degree of accuracy over long periods of use. Therefore, it was decided to use a Weidemann PS3M (averaging, separable) extensometer as a base unit for modification. Descriptions of extensometer modifications and supporting fixtures are given below.

\section{$\underline{\text { Transformer }}$}

The first step in the development was to achieve a thermally stable LVDT. Two electrically matching units are required in the null balance circuit: (1) the signal producing unit, and (2) the error balancing unit, Originally the units were purchased commercially, but are now handcrafted at a substantial cost savings.

A high temperature, nickel clad silver, magnet wire, which is insulated with a silicone ceramic compound, is wound onto a machined Lavite bobbin (body). The pigtails of the magnet wire are fused to the lead-in cable, and each bobbin coil and its junctions are then bound with fiberglass. tape, The completed coil assembly is fitted into a ferromagnetic case, which is in turn attached to the extensometer frame. Finally, the lead-in cable is insulated with fiberglass and clad with woven, flexible, stainless steel wrapping. Outer protection of the cable is required to minimize both abrasion of charred insulation and mechanical wear resulting from rough handling in remote facilities.

* Weidemann Machine Company (formerly Baldwin-Lima-Hamilton), King of Prussia, Pa. 


\section{Extensometer Frame}

Modifications to the extensometer frame consisted of replacing construction materials of key components in order to enable them to withstand elevated temperatures. These modifications are listed below. (Nomenclature for the components is given in Figure 1.)

Since the original aluminum structural components bend under stresses applied by the gage screws at elevated temperatures, new components were machined from Ti-6 Al-4 V alloy to obtain higher creep strength. The life of the gage screw points normally made of steel was extended by fabricating them out of titanium carbide which has a higher cold and hot hardness than steel. The angle of the gage screw point was changed to $75^{\circ}$ to facilitate penetration. Additional penetration is usually required to prevent unseating of the extensometer by differential thermal expansion during heating to test temperature. The amount of penetration must be carefully controlled, however, so that resulting stress raisers will not influence the test.

Elgiloy* was employed for the spring, which motivates the LVDT

core, in order to provide a useful spring constant at $500{ }^{\circ} \mathrm{C}$. The phenolic core spacer was replaced with $304 \mathrm{~L} \mathrm{SS}$, carefully machined to avoid martensite formation. Ferromagnetic materials, which alter the transformer coupling and the resulting magnification ratio and linearity, must be kept away from the magnetic field near the core.

The polished face on the core assembly was replaced with lapped and polished TiC. This prevents the brass follower on the bell crank from sticking or welding to the $\mathrm{TiC}$ face and allows free motion of the bell crank throughout its arc. A new bell crank was machined from Ti-6 Al-4 V alloy for its higher, elevated-temperature creep strength. Finally, capscrew socket heads were silver brazed to the gage screw heads on one side of the extensometer to permit remote operation with jig-mounted allen wrenches.

* Heat-resistant spring alloy manufactured by Elgin National Watch Company, Elgin, Illinois. 


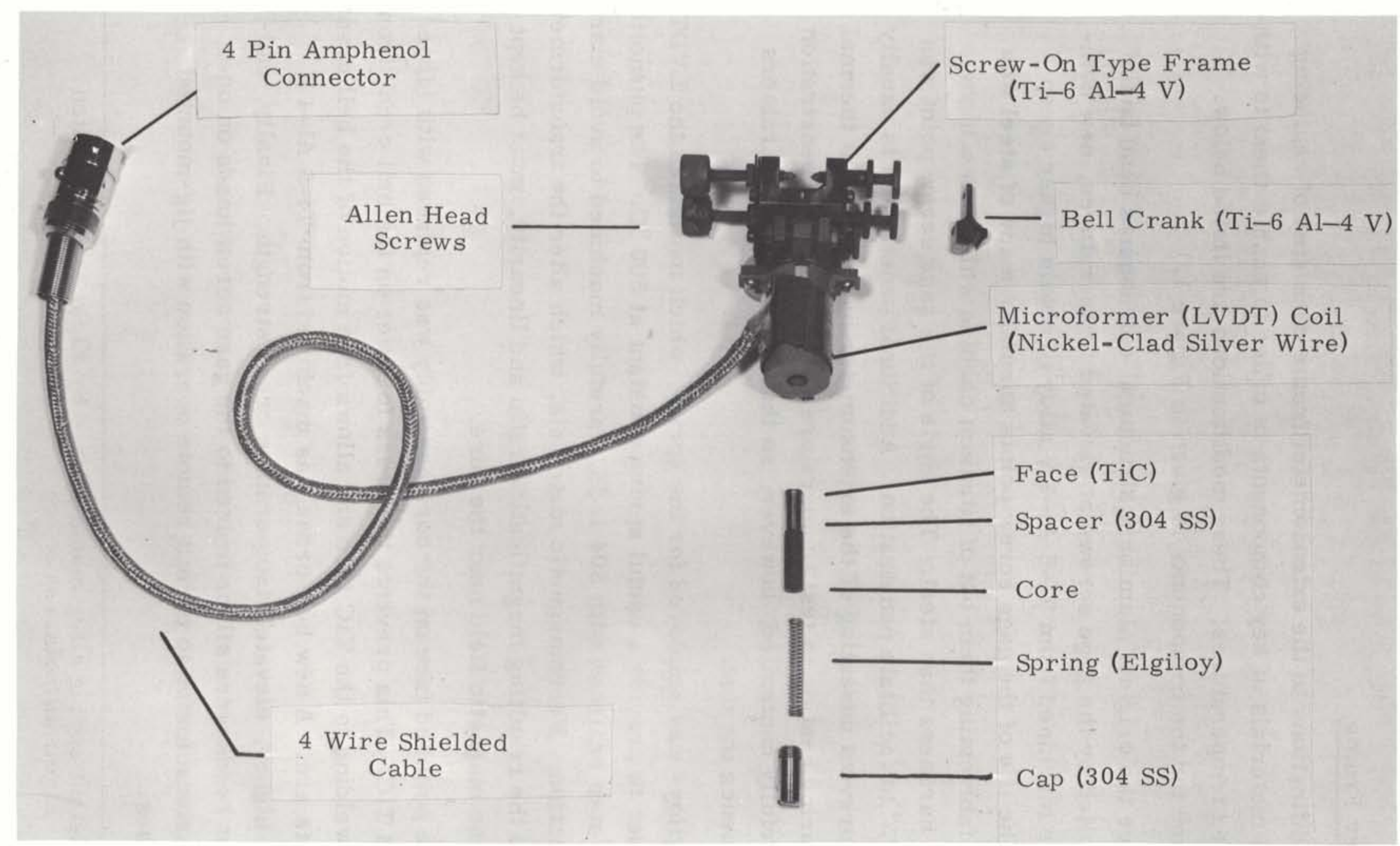

FIGURE 1

Neg. 0651143-2

0 to $500{ }^{\circ} \mathrm{C}$ Extensometer and Associated Parts 


\section{Calibrating Apparatus}

A Boeckeler, * nonrotating spindle, micrometer head (Figure 2) is attached to a rod passing through a tube assembly, which in turn protrudes into the environmental furnace. Here the extensometer is attached and calibrated at the specific test temperature. A cooling jacket prevents heating of the micrometer thread.

\section{Mounting Jig}

The mounting jig (Figure 3) serves several purposes:

- It automatically establishes the gage length of the extensometer (1.000 in. was selected).

- It holds the specimen so that the gage screws can be attached along the central axis of the specimen and on the gage portion of the reduced section.

- It serves as a hold-down fixture for remotely conducting the necessary attachment manipulations.

\section{Environmental Furnace}

The furnace used to provide heat for the test chamber employs a balanced motor and fan assembly which effectively eliminates thermal gradients along the specimen length. This apparatus is shown in Figure 4. Heat is provided by a pair of $115 \mathrm{~V}$ tubular-sheathed elements. The furnace shell and fan are constructed of 300 series stainless steel to facilitate decontamination. Temperature control is provided by a current adjusting, three mode controller.

Calibration, Operation, and Maintenance

Calibration is accomplished by attaching an extensometer to the oven-mounted calibration apparatus so that the extensometer is translated by turning the Boeckeler screw.

* Precision Micrometer manufactured by Arizona Tool and Die Company, Tucson, Arizona. 


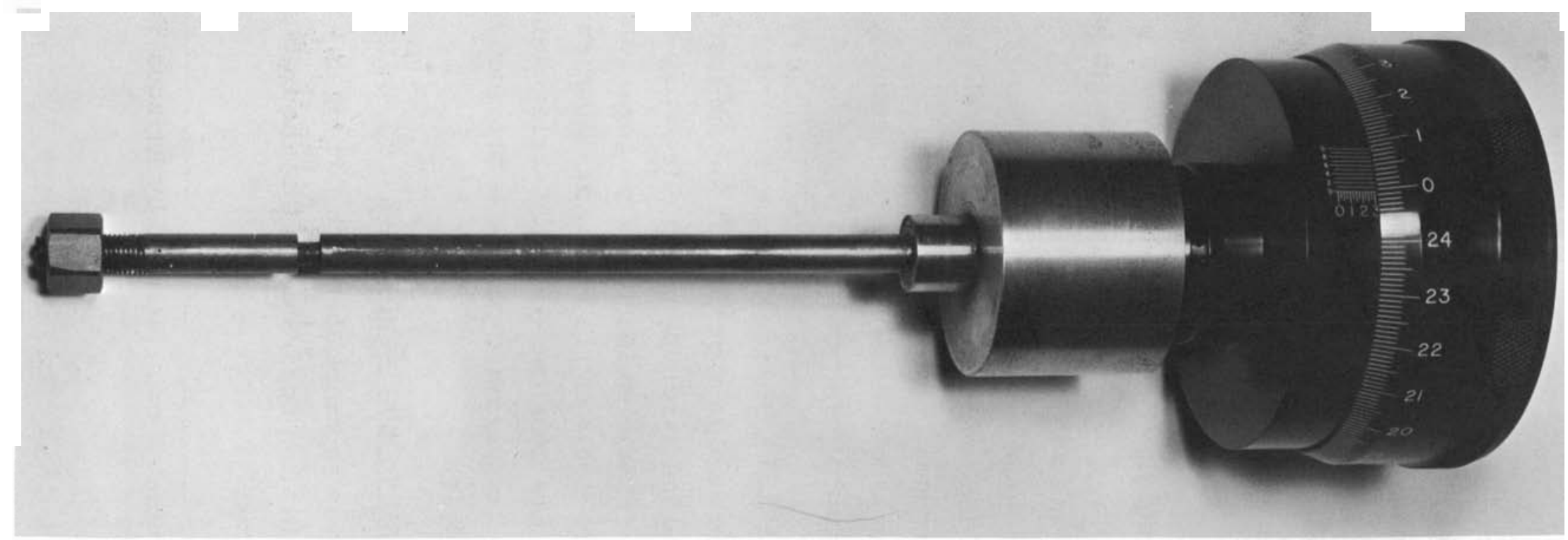

\section{FIGURE 2}

Calibration Apparatus

(The Boeckeler nonrotating spindle micrometer head is attached to a rod passing through a tube, which in turn protrudes into the environmental oven.) 


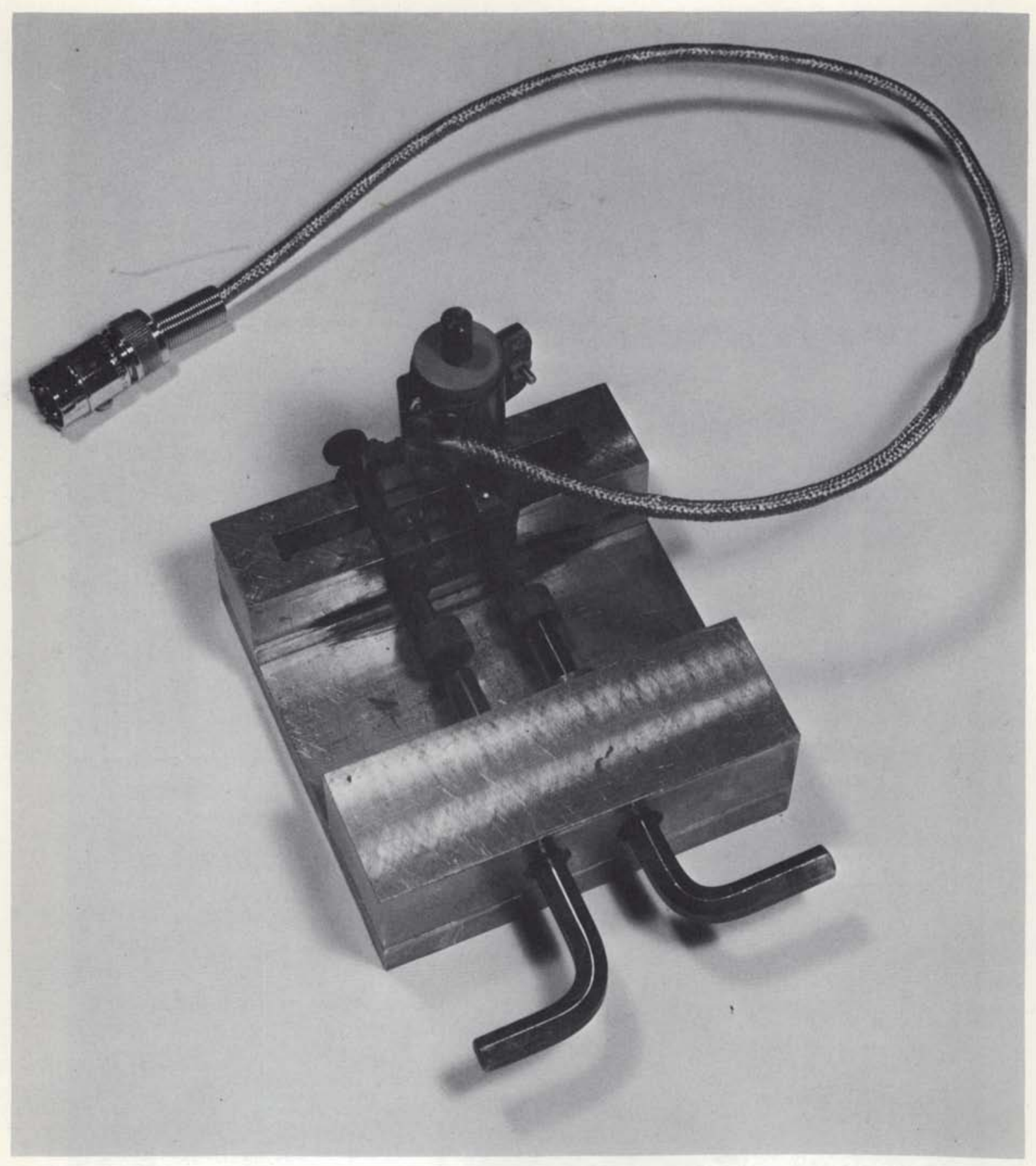

FIGURE 3

Extensometer Mounting Jig

Neg. 0651143-3 


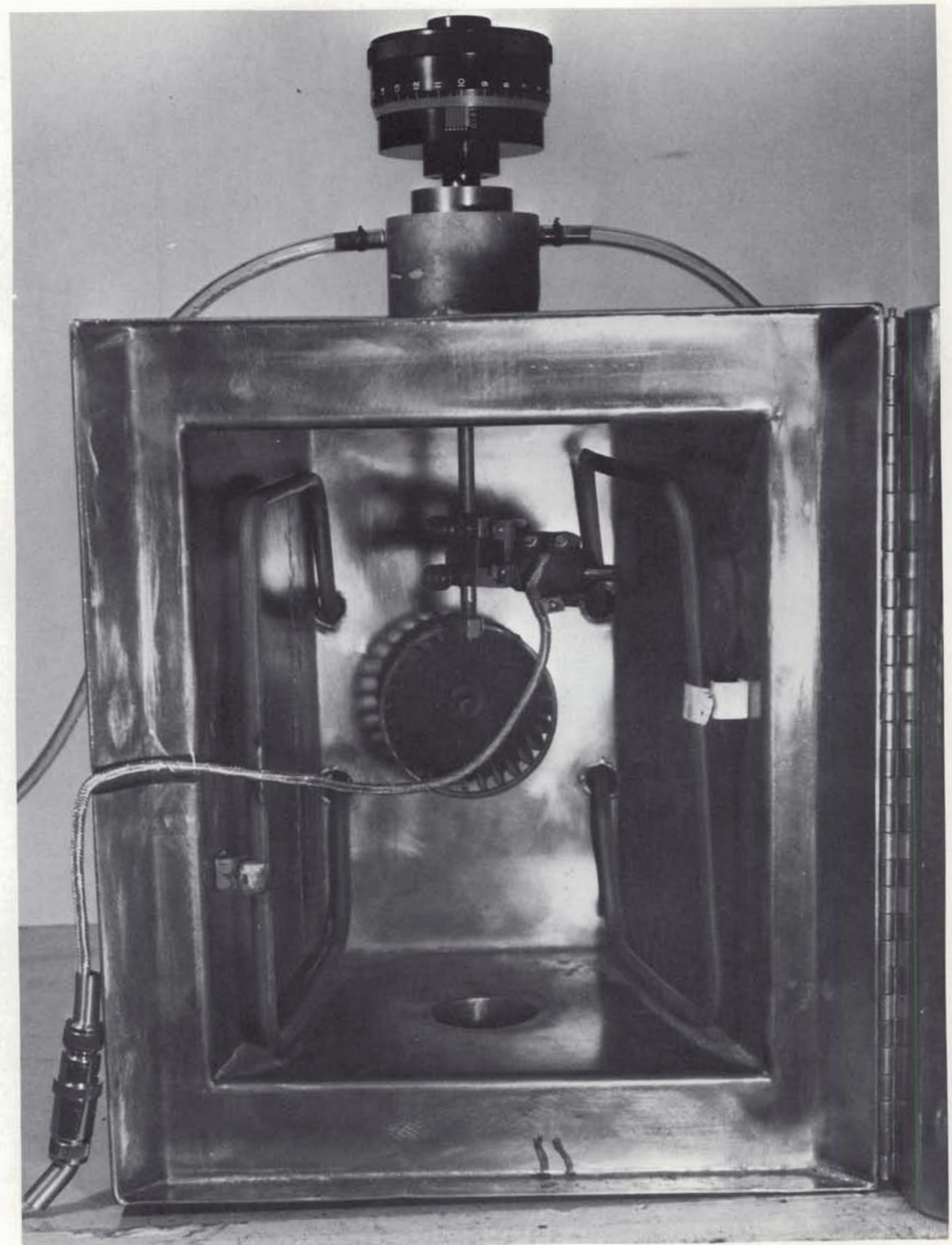

FIGURE 4

Environmental Furnace and Calibration Arrangement (Note the cooling jacket for the micrometer head)

Neg. 0651143-5 
The calibrating procedures used are those outlined in the Instron operating manual. To obtain $1000 \mathrm{X}$ magnification on the recorder, the amplifier is adjusted to give 10. 0 in. of chart motion for $0.0100 \mathrm{in}$. of motion from the Boeckeler screw. Linearity is measured by driving the extensometer in $0.001 \mathrm{in.}$ increments over its normally used range. This is repeated several times to minimize errors. A typical calibrating record is illustrated in Figure 5. Once the extensometer has been calibrated at the selected testing temperature, periodic verification of the magnification ratio and linearity is made.

Remote operation requires the use of the jig illustrated in Figure 3. An irradiated specimen is first placed in the central slot of the jig. After verifying the specimen alignment, the extensometer is placed in the jig with the gage screws loosened. The gage points are then tightened against the specimen with allen wrenches. Finally, the extensometer-specimen assembly is removed from the jig and mounted in the tensile grips, as shown in Figure 6. The furnace is then heated to test temperature and the test begun.

After the test specimen has yielded plastically, the extensometer signal is switched off, and the remainder of the load-extension curve is obtained by timed chart travel. The extensometer is designed to separate at or near fracture. After completion of the test, the gage screws are retracted, the extensometer removed, the broken specimen pieces removed from the grips, and the extensometer reassembled for the next test,

The stress-strain curves in Figure 7 illustrate the differences in apparent strain as exhibited by two strain measuring methods: (1) use of the extensometer past the yield point and then use of crosshead travel to fracture, and (2) crosshead travel only. Both tests were performed on 316-L SS which was cold-worked $25 \%$ by rolling. Specimens having a gage length of $2.125 \mathrm{in}$, were machined from the rolled plate with the specimen axis transverse to the rolling direction. The tests were conducted at $500{ }^{\circ} \mathrm{C}$ at a crosshead speed of 0.005 in. $/ \mathrm{min}$. 


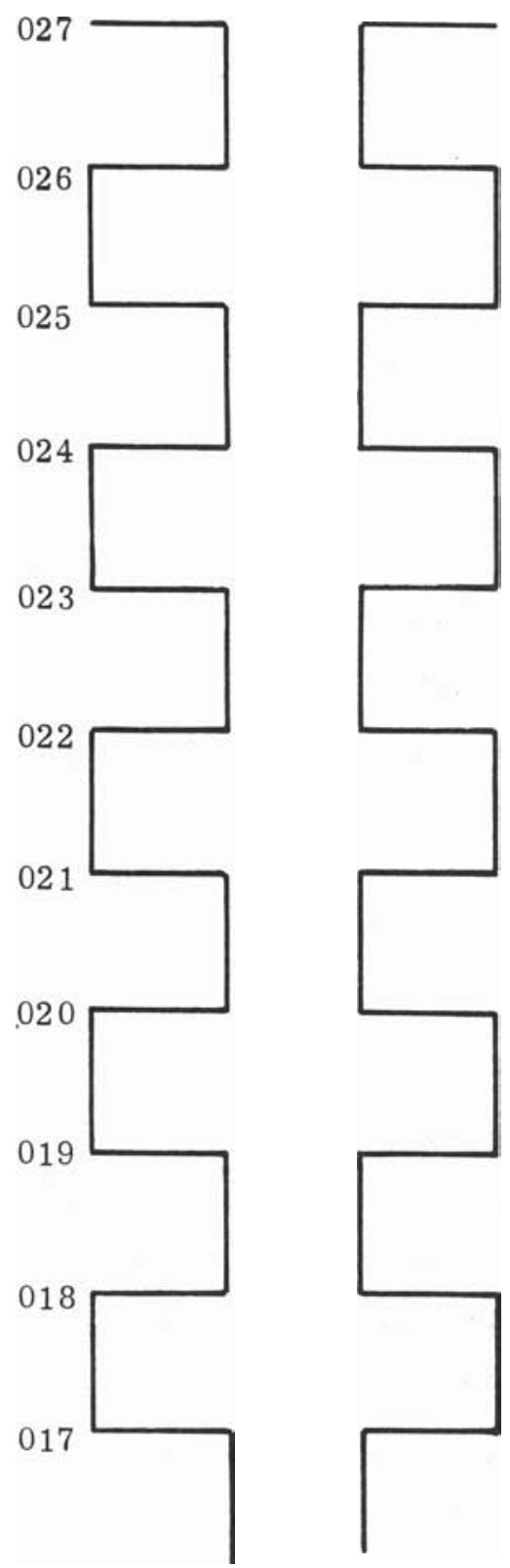

1. Method of Calibration Extensometer Comparator

2. Source of Calibration Apparatus Boeckeler Nonrotating Spindle Micrometer Head Arizona Tool \& Die Co.

3. Verification of Calibration Apparatus a s Specified by Manufacture

4. Errors of Calibration Apparatus Maximum Error at Any Setting Within $\pm 0.000015 \mathrm{in.} / \mathrm{in}$. of Travel

5. Identification of Extensometer BNW-0-500C

6. Gage Length of Extensometer - 1.0 in.

8

7. Position of Extensometer During Calibration $\rightarrow \quad$ Attached to 0.375 diam Spindles with Axis Vertical

8. Temperature of Extensometer During Calibration $-500{ }^{\circ} \mathrm{C} \pm 1{ }^{\circ} \mathrm{C}$

9. Method of Attachment to Calibration Apparatus by Four Pointed Gage Screws

10. Record of Reading as per Graph

11. Calibration Factor -0.001

12. Error of Extensometer for Each Reading a s Measured on Graph - Maximum Error $0.000080 \mathrm{in}$.

13. Class of Extensometer - B-1

14. Date of Calibration - July 7, 1965

\section{FIGURE 5}

Typical Calibration Record and Classification of Extensometer 


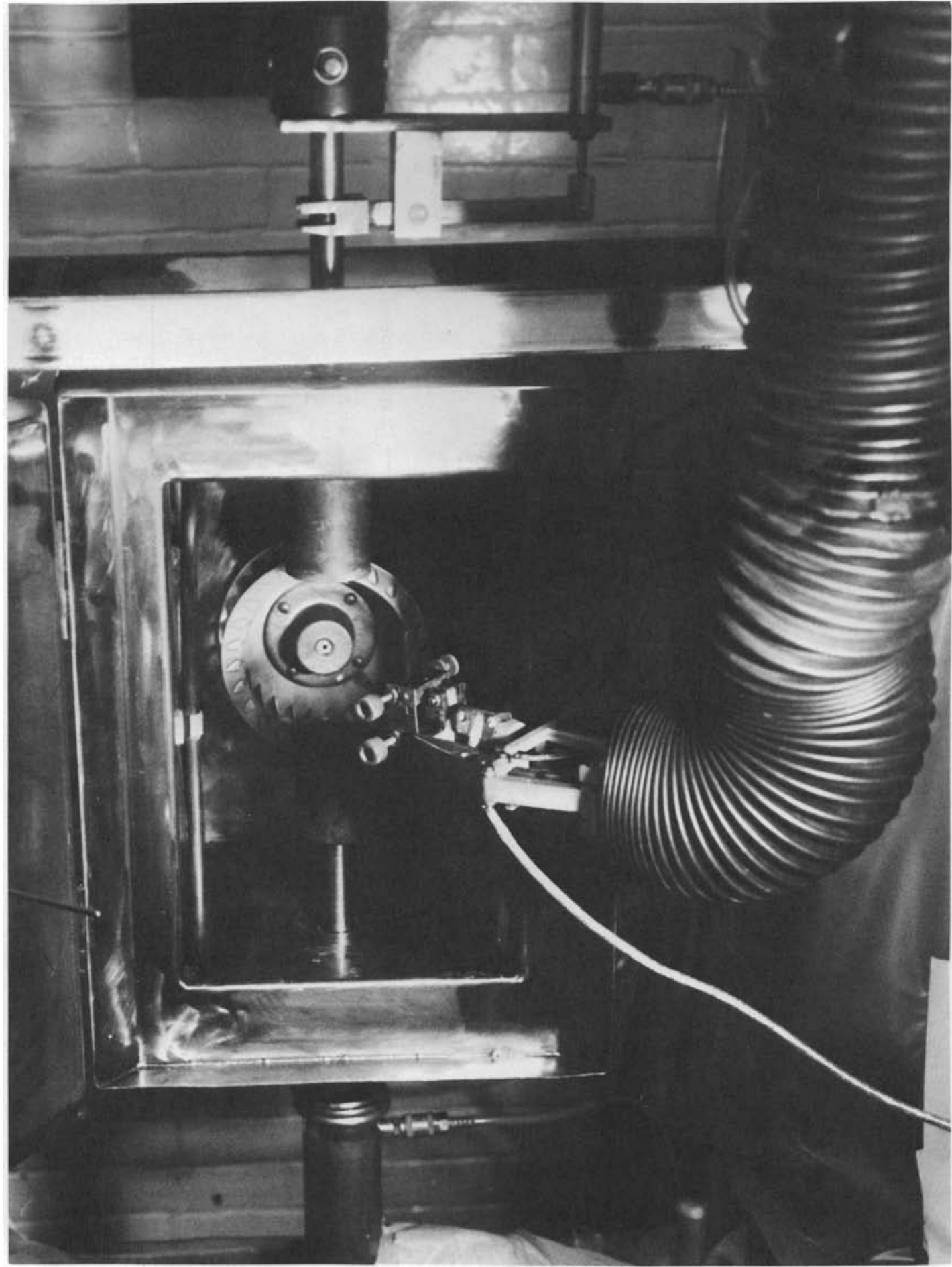

FIGURE 6

Placement of Specimen and Extensometer into Test Position with Manipulators

Neg. 0651143-1 


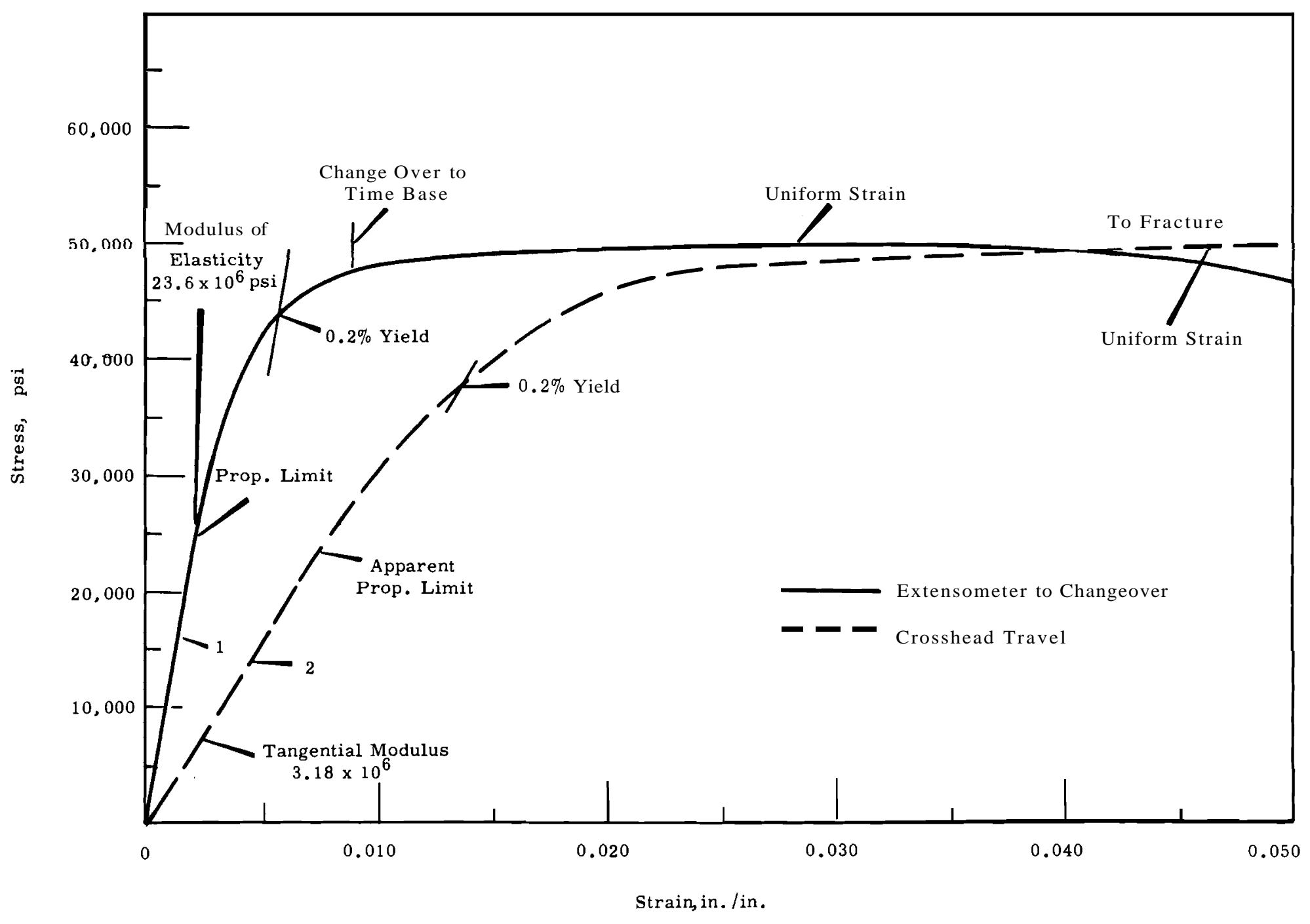

Stress Strain Curves Illustrating the Difference in Apparent Strain As Measured by Extensometer and by Crosshead Travel 
Referring to Figure 7, the use of crosshead travel as a measure of specimen extension results in considerable errors in property measurements due to elastic takeup in the load train. Whereas the modulus of elasticity measured with the extensometer agrees with published values, the modulus determined by crosshead motion is low by a factor of 8 . This deficiency also causes sizable errors in values of yield strength and uniform strain derived from the stress-strain curve.

Frequent maintenance of the elevated-temperature extensometers is required due to seizing, galling, oxidation, mechanical wear, and dimensional changes with increasing temperature. Alcohol dag is applied as a lubricant to all sliding parts and to the gage screw threads every few tests. Taps and dies are used periodically to chase the threads of the gage screws and bushings, thereby extending their life. There is no substitute for care, since these instruments become hypersensitive to any type of abuse at elevated temperatures.

$\underline{\text { ACKNOWLEDGEMENTS }}$

The authors would like to express their appreciation to members of the Pacific Northwest Laboratory Technical Shops Operation, and to thank A. L. Bement and J. E. Irvin for their interest and encouragement on this project. 


\section{ONSITE DISTRIBUTION}

Copy Number

$\underline{\text { Pacific Northwest Laboratory }}$

$\begin{array}{ll}1 & \text { R. C. Aungst } \\ 2-11 & \text { R. W. Barker } \\ 12-21 & \text { A. L. Bement } \\ 22 & \text { T. K. Bierlein } \\ 23 & \text { W. A. Briggs } \\ 24 & \text { S. H. Bush } \\ 25 & \text { J. J. Cadwell } \\ 26 & \text { J. W. Carter } \\ 27 & \text { T. T. Claudson } \\ 28 & \text { L. J. Defferding } \\ 29 & \text { R. F. Dickerson } \\ 30 & \text { R. L. Dillon } \\ 31 & \text { M. C. Frazer } \\ 32 & \text { N. E. Harding } \\ 33 & \text { G. L. Hood } \\ 34 & \text { J. L. Humason } \\ 35 & \text { J. E. Irvin } \\ 36 & \text { M. D. Jones } \\ 37 & \text { A. J. Karnie } \\ 38 & \text { R. S. Kemper } \\ 39 & \text { G. A. Last } \\ 40 & \text { R. C. Lawrence } \\ 41 & \text { R. D. Leggett } \\ 42 & \text { I. S. Levy } \\ 43-52 & \text { P. K. McDaniel } \\ 53 & \text { J. E. Minor } \\ 54 & \text { R. D. Nelson } \\ 55 & \text { D. H. Nyman } \\ 56 & \text { D. P. OiKeefe } \\ 57 & \text { R. E. Olson } \\ 58 & \text { P. J. Pankaskie } \\ 59 & \text { R. G. Rowe } \\ 60 & \text { F. E. Say } \\ 61 & \text { F. A. Smidt Jr. } \\ 62 & \text { W. F. Smith } \\ 63 & \text { H. A. Taylor } \\ 64 & \text { F. W. VanWormer } \\ 65 & \text { K. R. Wheeler } \\ 66 & \text { R. G. Wheeler } \\ 67 & \text { R. D. Widrig } \\ 68 & \text { J. A. Williams } \\ 69-73 & \text { Technical Information Files } \\ 74 & \text { Technical Publications-300 Areations-700 Area } \\ 75-76 & \text { Technical Publications } \\ & \end{array}$


BNWL-148

ONSITE DISTRIBUTION (contd)

Copy Number

$\underline{\text { Richland Operations Office }}$

77

78

R. K. Sharp

Technical Information Library

OFFSITE DISTRIBUTION

Number of Copies

6

Argonne National Laboratory

Attn: R. J . Armani

T. H. Blewitt

J. H. Kittel

F. D. McGinnis - EBR-I, Idaho Falls, Idaho

A. D. Rossin

D. K. Youngdahl

1

Battelle Memorial Institute

Attn: F. R. Shober

3

Brookhaven National Laboratory

Attn: J。G. Y。 Chow

D. H. Gurinsky

S. B. McRickard

2

General Atomic Division

Attn: T. A. Trozera

W. P. Wallace

4

General Electric Company, Richland

Attn: D. H. Curtiss

M. C. Leverett

M. Lewis

J. W. Riches

Naval Research Laboratory

Attn: J. W. Hawthorne

L. E. Steele

Nuclear Materials and Propulsion Operation

Attn: C. L. Brassfield

F. E. Kingsbury

J. McGurty

J. Moteff

R. C. Rau

F. C. Robertshaw

J. R. Smith 


\section{OFFSITE DISTRIBUTION (SPECIAL)(contd)}

Number of Copies

10

2

Oak Ridge National Laboratory

Attn: R. G. Berggren

W. E. Brundage

N. E. Hinkle

E. C. Miller

S. M. Ohr

J. T. Stanley

M. S. Wechsler

J. R. Weir

J. M. Williams

F. W. Young

Phillips Petroleum Company

Attn: J. M. Beeston

W. C. Francis

USAEC - Chicago Operations Office

Attn: Claude Pursell

USAEC - Idaho Operations Office

Attn: J. F. Kaufmann

USAEC - Oak Ridge Operations Office

Attn: D. F. Cope

USAEC - Washington, D. C.

Division of Licensing and Regulation

Attn: M. Bolotsky

E. G. Case

J. J DiNunno

A. B. Holt

Division of Reactor Development

Attn: I. H. Mandil

J. L. Mershon

W. L. R. Rice

J. M. Simmons

R. H. Steele

S. A. Szawlewics

N. J. Triner

Division of Research

Attn: D. K. Stevens

NASA Lewis Research Center

Attn: M. L. Ault

General Electric Company, Pleasanton

Attn: L. P. Bupp

E. A. Evans 


\section{OFFSITE DISTRIBUTION (SPECIAL)(contd)}

Number of Copies

1

1

1

1

1

1

1
J. A. Erlewine

Senior AEC Representative, Brussels Office

U. S. Mission to the European Communities

23 Avenue des Artes

Brussels, Belgium

R. H. Fillnow

Bettis Power Laboratory

P. O. Box 1468

Pittsburgh, Pennsylvania

A. E. Focke

University of Cincinnati

Department of Chemical Engineering and Metallurgical Engineering

Cincinnati 21, Ohio

R. F. Fraley

Executive Secretary

Advisory Committee on Reactor Safeguards

U. S. Atomic Energy Commission

Washington, D. C. 20545

John Gibbons

Combustion Engineering Corporation

Windsor, Conn.

J. F. Haines

Nuclear Power Department, Washington

Atomic Energy Division

Allis-Chalmers Manufacturing Company

508 Kennedy Stress, N. W.

Washington 11, D. C.

E. T. Hayes

Special Assistant for Materials

DDR\&E

The Pentagon

Washington 25, D. C.

George Knighten

Nuclear Power Field Office

Engineer Research and Development Center

Fort Belvoir, Virginia 22060

M. Krasner

Nuclear Reactor Division

Lewis Research Center

21000 Brookpark Road

Cleveland 35, Ohio 


\section{OFFSITE DISTRIBUTION (SPECIAL)(contd)}

Number of Copies

1

1

1

1

1

1

1
E. Landerman

Westinghouse Electric Corporation

Atomic Power Division

P. O. Box 355

Pittsburgh 30, Pennsylvania

J. R. Lane

Materials Advisory Board

National Academy of Sciences

2101 Constitution Avenue, N. W.

Washington 25, D. C.
A. T. Lovell
Nuclear Materials and Propulsion Operation
National Reactor Test Station
P. O. Box 2147
Idaho Falls, Idaho
S. G. Nordlinger
AEC Scientific Representative
USAEC London Office
U. S. Embassy
London, England
J. W. Norris
Chief, Cataloging Branch
U. S Atomic Energy Commission
Division of Technical Information Extension
P. O. Box 62
Oak' Ridge, Tennessee 37831

H. J. Pess 1

Route 1, Box 892

Hood River, Oregon

L. M. Raring

Pratt \& Whitney Aircraft Division

CANEL Operation

P. O. Box 611

Middletown, Connecticut

Headquarters

Directorate of Materials and Processes

Aeronautical Systems Division

Air Force Systems Command

U. S. Air Force

Attn: Col. L. J. Standifer

Wright-Patterson Air Force Base, Ohio 


\section{OFFSITE DISTRIBUTION (SPECIAL)(contd)}

Number of Copies

1

1
J. Van Ullen

Knolls Atomic Power Laboratory

P. O. Box 1072

Schenectady, New York

C. Washburn

Reactor Division

U.S. Atomic Energy Commission San Francisco Operations Office 2111 Bancroft Way

Berkeley, California 94704 